\title{
Efficacy of Omalizumab in Treatment of Therapy-Resistant Atopic Dermatitis and Contact Dermatitis
}

\author{
Omalizumabin Tedaviye Dirençli Atopik Dermatit ve Kontakt Dermatit Tedavisindeki Etkinliği
}

\author{
(1) Funda Tamer ${ }^{1}$, (1) Fatma Gülru Erdoğan ${ }^{1}$, (1) Dilsun Yıldırım², (1) Didem Dinçer Rota1 \\ 1 Ufuk University Faculty of Medicine, Department of Dermatology, Ankara, Turkey \\ 2 Şırnak State Hospital, Clinic of Dermatology, Şırnak, Turkey
}

\section{Abstract}

Omalizumab selectively binds to immunoglobulin E antibodies and is approved for treatment of allergic asthma. However, its use in dermatologic diseases is increasing. Here, we report three treatment resistant cases, one with atopic dermatitis the other two with contact dermatitis successfully treated with omalizumab with no side effect.

Key Words: Atopic Dermatitis, Contact Dermatitis, Omalizumab

\section{Öz}

Omalizumab selektif olarak immünoglobulin E antikorlarına bağlanır ve alerjik astım tedavisi için onaylanmıştır. Bununla birlikte dermatolojik hastalıklarda kullanımı giderek artmaktadır. Bu makalede, omalizumab ile başarılı bir şekilde ve yan etki görülmeden tedavi edilmiş biri atopik dermatitli, diğer ikisi kontakt dermatitli olmak üzere tedaviye direnç gösteren üç olgu sunduk.

Anahtar Kelimeler: Atopik Dermatit, Kontakt Dermatit, Omalizumab

\section{Introduction}

Omalizumab is a recombinant immunoglobulin (Ig) $\lg \mathrm{G} 1$ monoclonal antibody binding to serum free lgE, leading to down-regulation of IgE receptors and thus mediator release of basophils and mast cells (1).

Although mostly used for chronic idiopathic urticaria, uses in atopic dermatitis, bullous pemphigoid, hyper-lgE syndrome, and toxic epidermal necrolysis are recently reported (2).

\section{Case Reports}

\section{Case 1}

A 28-year-old Caucasian male with atopic dermatitis since the age of two had been treated with systemic cyclosporine (5 g/kg/day for three years), azathioprine (100 mg/day for six months), mycophenolate mofetil (2 g/day for one year); narrow-band ultraviolet B (NB-UVB) and psoralen plus UV a phototherapy (PUVA) without benefit. To assist these agents he also received systemic corticosteroid injections at least four times a year together with topical corticosteroids, tacrolimus, emollients and systemic antihistamines, However, none of these reached even near-complete healing. He also had allergic rhinitis, conjunctivitis and asthma. His mother, uncle and younger sister had atopic dermatitis too. He had widespread erythematous lesions on the chest, back, inguinal region, arms, popliteal fossae, face, neck and sacral area (Figure 1a, b). The patient's SCORAD index was 46 . Total serum IgE level was 5335.6 $\mathrm{IU} / \mathrm{mL}$ (normal range: $0-100$ ), total serum eosinophil count was 230/ $\mathrm{mm}^{3}$ (normal range: 40-400). Omalizumab $300 \mathrm{mg} / \mathrm{month}$ subcutaneously is started. Patient had partial response after five months. However, he did not need any systemic corticosteroid injections. Therefore, dose of omalizumab is increased to 450 
$\mathrm{mg} /$ month. After three more months, a better clinical response was achieved (Figure 2a, b). Total IgE level was $677.4 \mathrm{IU} / \mathrm{mL}$, eosinophil count was $99 / \mathrm{mm}^{3}$ and SCORAD index was 18 at the end of the 24-month-therapy. Patient never received steroid injections and was clear of symptoms of allergic rhinitis and asthma.

\section{Case 2}

A 64-year-old Caucasian male had pruritic rash on arms and legs with a diagnosis of contact dermatitis for seven years. He also had systemic hypertension and Familial Mediterranean Fever and was receiving oral colchicine $1 \mathrm{~g}$ /day for the last ten years. The patient was treated with topical and systemic steroids, tacrolimus, pimecrolimus, and NB-UVB. Nevertheless, no satisfactory clinical response was achieved. Patch test was positive to cobalt, nickel sulfate, potassium dichromate and formaldehyde. He had erythematous lesions on arms, legs, gluteal region and bilateral palmar regions (Figure 3a). Meanwhile, serum total IgE level was $25 \mathrm{IU} / \mathrm{mL}$ and total serum eosinophil count was $231 / \mathrm{mm}^{3}$. Omalizumab $300 \mathrm{mg}$ was

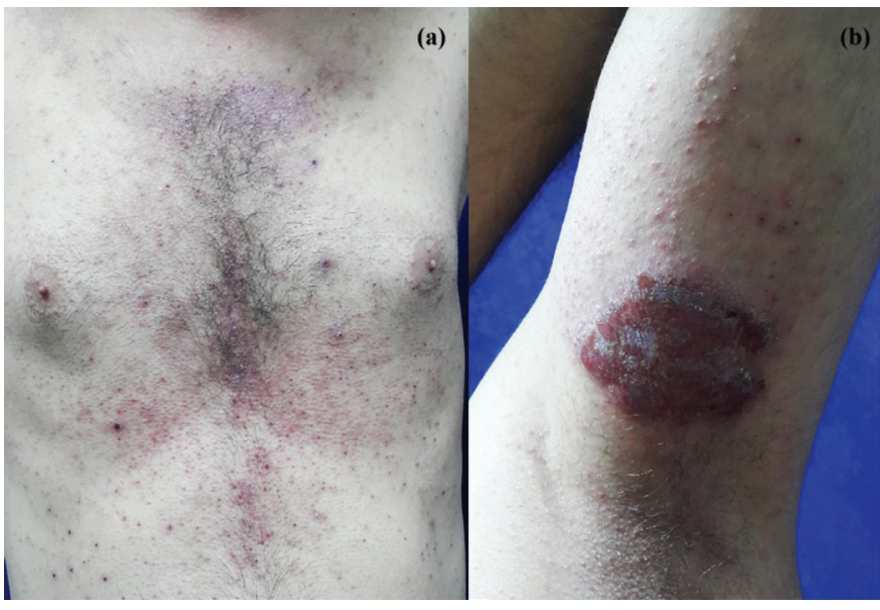

Figure 1: a) Erythematous squamous papules and plaques on the trunk before therapy, b) Erythematous infiltrated annular plaque on the flexural surface of the left arm before therapy

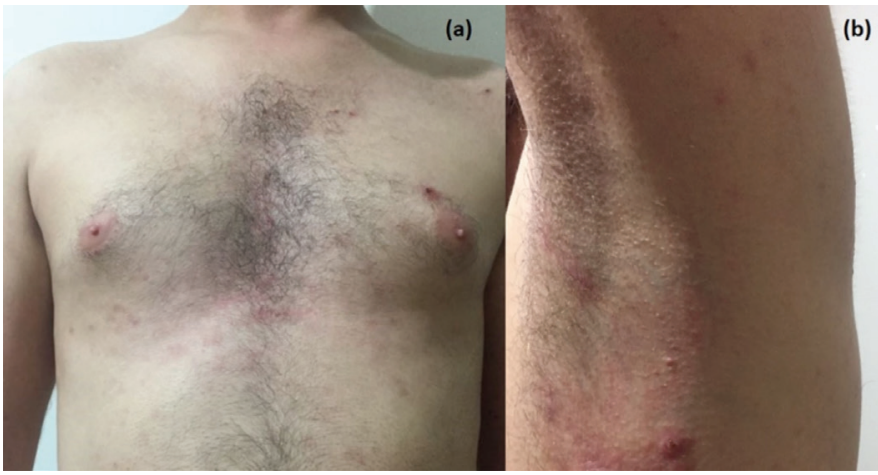

Figure 2: Erythematous lesions on the trunk a) and left arm b) were regressed after therapy started every four weeks. Lesions healed completely after first injection (Figure 3b). On eighth month total serum IgE level was $17 \mathrm{IU} / \mathrm{mL}$ and total serum eosinophil count was $243 / \mathrm{mm}^{3}$. No side effect was observed.

\section{Case 3}

A 57-year-old Caucasian male presented with a ten-month history of pruritic lesions on his arms. Patient stated exposure to garden chemicals for a few weeks after which the lesions started. Past medical history revealed gout, hypertension and coronary artery disease. He had erythema on the extansor surfaces of hands and forearms (Figure 4a). Prick test was positive for aspergillus mould, peach, walnut, orange, banana, tea, paprica, onion, cocoa, mosquito, secale cereale, composite and chicken meat. Patch test was positive for formaldehyde and mercaptobenzothiazole. Skin biopsy supported the diagnosis of allergic contact dermatittis. Serum total IgE level was 10.1

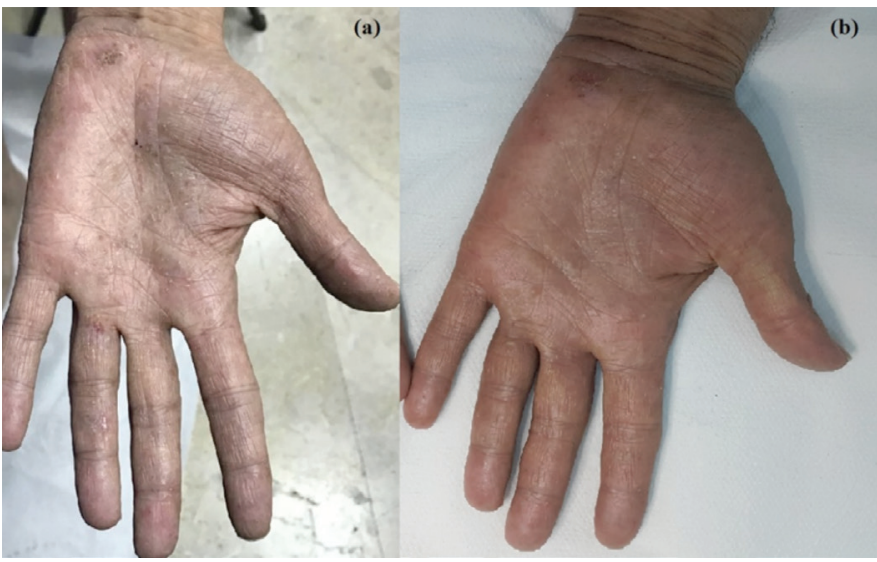

Figure 3: a) Erythematous papules on the palmar region before therapy, b) after therapy

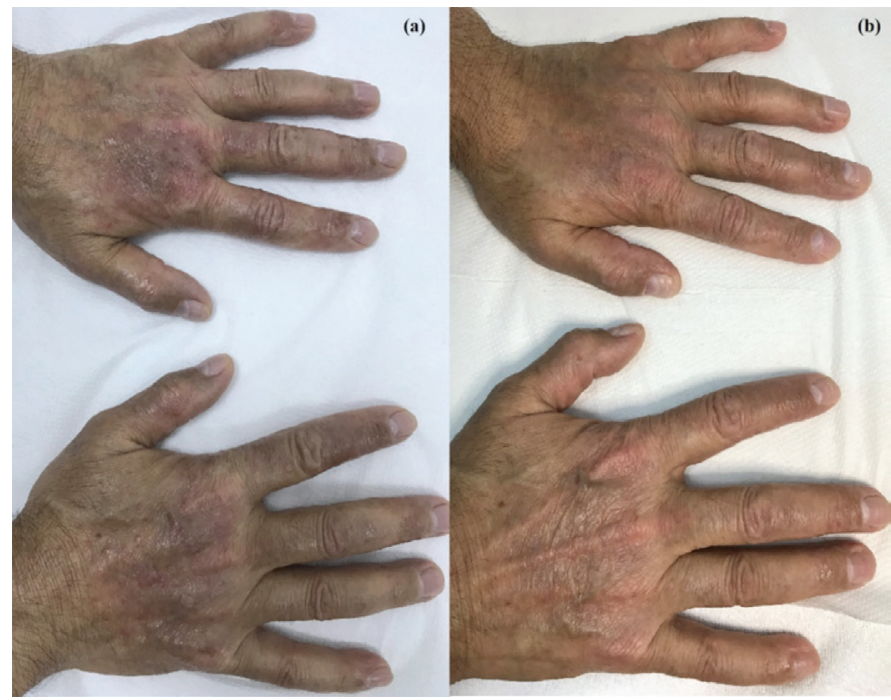

Figure 4: a) Erythematous plaques on the dorsal surface of the hands, b) Lesions disappeared after therapy 
$\mathrm{IU} / \mathrm{mL}$ and total serum eosinophil count was $316 / \mathrm{mm}^{3}$ Patient received topical and systemic steroid plus local PUVA three times a week $\left(0.5-1.7 \mathrm{j} / \mathrm{cm}^{2}\right)$ for seven weeks with no improvement. Omalizumab $300 \mathrm{mg}$ is started every four weeks. Lesions healed completely following first injection (Figure 4b). After three injections, serum total IgE level and total serum eosinophil count were $43.8 \mathrm{IU} / \mathrm{mL}$ and $199 / \mathrm{mm}^{3}$, respectively.

\section{Discussion}

Atopic dermatitis is a chronic condition affecting 1-3\% of adults usually coexisting with allergic asthma, rhinitis and food allergy (3). Expression of high affinity lgE receptors on the surface of dendritic cells aggrevates atopic dermatitis lesions $(4,5)$. Increased number of eosinophils is shown in skin lesions which play role in inflammation and immune cell interactions (3). Conventional drugs such as systemic corticosteroids, antihistamines and cyclosporine usually don't achieve complete healing in severe cases (6). Omalizumab, being a recombinant anti-lgE antibody, is also used in atopic dermatitis with controversial results (7). In two randomized controlled studies and 13 case series a total of 103 patients were evaluated, 60.5\% of these with severe disease; and $43.4 \%$ with serum IgE levels greater than $5000 \mathrm{IU} / \mathrm{mL}$. Most patients (66.7\%) needed 600 mg or higher doses every four weeks still, treatment failed in $30.1 \%$. There was a better clinical response in patients with serum IgE levels lower than $700 \mathrm{IU} / \mathrm{mL}$ (8). Zink et al. (9) treated ten patients with severe and recalcitrant atopic dermatitis with a combination of immunoadsorption and omalizumab. They suggest that immunoadsorption decreasing highly elevated serum IgE concentration before omalizumab injection may increase clinical response (9). We experienced excellent clinical outcome with our atopic dermatitis patient. Serum IgE level was elevated and total eosinophil count was in normal limits at the start. However, patient showed a gradual but marked decrease in serum lgE level and total eosinophil counts. Omalizumab may be effective in atopic dermatitis, with both its anti-lgE, and eosinophil apoptosis effects.

Allergic contact dermatitis, on the other hand; is a common disease caused by chronic antigenic stimulation. It is a type 4 hypersensitivity reaction mediated mainly by $T$ lymphocytes. It is important to determine the allergen(s) for effective treatment $(10,11)$. However, it is not always easy to isolate and/or to avoid allergens. Therefore, allergic contact dermatitis is usually recurrent, chronic and treatment resistant. Systemic and topical corticosteroids, calcineurin inhibitors, NB-UVB, PUVA, cyclosporine, azathioprine, mycophenolate and acitretin are treatment options. Lately, efficacy of biologic agents like dupilumab [interleukin (IL)-4/IL-13 antagonist] or tocilizumab (IL-6 antagonist) is debated (11). Another off-label use of omalizumab is in contact dermatitis. Mur
Gimeno et al. (12) reported a 38-year-old male patient with widespread occupational wheat contact dermatitis lesions treated with $225 \mathrm{mg}$ of omalizumab every two weeks. Clinical improvement was observed at the first month of therapy with complete clearence in 4 months (12). Clinical experience with omalizumab in treatment of allergic contact dermatitis is still insufficient. Mechanism of action is also not well understood. However, it is suggested that omalizumab can induce eosinophil apoptosis, reduce granulocyte-macrophage colony-stimulating factor production from lymphocytes, inhibit the release of pro-inflammatory mediators from mast cells or basophils and inhibit allergen-induced lymphocyte differentiation (13). It also inhibits differentiation of T lymphocytes to T-helper $2\left(\mathrm{~T}_{\mathrm{H}} 2\right)$ by reducing IgE receptors on these cells. It results in reduced $\mathrm{T}_{\mathrm{H}} 2$ cell differentiation to inhibit the allergic immune response. Downregulation of IgE receptor expression on dendritic cells also inhibits antigen presentation to T lymphocytes $(13,14,15)$. Our patients with chronic systemic contact dermatitis had normal $\lg$ E levels and eosinophil counts allthrough their treatments which does not seem to be associated with clinical improvement. Therefore, we may suggest that omalizumab shows its effect through reduced dendritic cell and lymphocyte activation and reduced $\mathrm{T}$ helper action in patients with chronic systemic contact dermatitis.

\section{Ethics}

Informed Consent: Written consent was obtained from all patients.

\section{Authorship Contributions}

Surgical and Medical Practices: F.G.E., D.D.R., F.T., D.Y., Concept: F.G.E., Design: F.G.E., F.T., Data Collection or Processing: F.T., D.Y., Analysis or Interpretation: F.G.E., D.D.R., Literature Search: F.G.E., F.T., Writing: F.G.E., F.T.

Conflict of Interest: No conflict of interest was declared by the authors.

Financial Disclosure: The authors declared that this study received no financial support.

\section{References}

1. El-Qutob D. Off-label uses of omalizumab. Clin Rev Allergy Immunol 2016;50:84-96.

2. Chia JC, Mydlarski PR. Dermatologic uses of omalizumab. J Dermatolog Treat 2017;28:332-337.

3. Peng $W$, Novak N. Pathogenesis of atopic dermatitis. Clin Exp Allergy 2015;45:566-574.

4. Novak N. An update on the role of human dendritic cells in patients with atopic dermatitis. J Allergy Clin Immunol 2012;129:879-886.

5. Tang TS, Bieber T, Williams HC. Are the concepts of induction of remission and treatment of subclinical inflammation in atopic dermatitis clinically useful? J Allergy Clin Immunol 2014;133:1615-1625. 
6. Kim DH, Park KY, Kim BJ, et al. Anti-immunoglobulin E in the treatment of refractory atopic dermatitis. Clin Exp Dermatol 2013;38:496-500.

7. Park SY, Choi MR, Na Jl, et al. Recalcitrant atopic dermatitis treated with omalizumab. Ann Dermatol 2010;22:349-352.

8. Wang HH, Li YC, Huang YC. Efficacy of omalizumab in patients with atopic dermatitis: A systematic review and meta-analysis. J Allergy Clin Immunol 2016;138:1719-1722.

9. Zink A, Gensbaur A, Zirbs $M$, et al. Targeting $\lg E$ in severe atopic dermatitis with a combination of immunoadsorption and omalizumab. Acta Derm Venereol 2016;96:72-76.

10. Mowad CM, Anderson B, Scheinman $P$, et al. Allergic contact dermatitis: Patient management and education. J Am Acad Dermatol 2016;74:10431054.
11. Kostner L, Anzengruber F, Guillod C, et al. Allergic contact dermatitis. Immunol Allergy Clin North Am 2017;37:141-152.

12. Mur Gimeno $P$, Martín Iglesias $A$, Lombardero Vega $M$, et al. Occupational wheat contact dermatitis and treatment with omalizumab. J Investig Allergol Clin Immunol 2013;23:287-288.

13. Massanari M, Holgate ST, Busse WW, et al. Effect of omalizumab on peripheral blood eosinophilia in allergic asthma. Respir Med 2010;104:188196.

14. Holgate $S$, Casale $T$, Wenzel $S$, et al. The anti-inflammatory effects of omalizumab confirm the central role of IgE in allergic inflammation. J Allergy Clin Immunol 2005;115:459-465.

15. Prussin C, Griffith DT, Boesel KM, et al. Omalizumab treatment downregulates dendritic cell FcepsilonRI expression. J Allergy Clin Immunol 2003;112:1147-1154. 